\title{
Kemampuan Berpikir Kritis Siswa Pada Implementasi Project Based Learning (PJBL) Berpendekatan Saintifik
}

\author{
Farida Daniel ${ }^{1)}$ \\ 1) Prodi Pendidikan Matematika STKIP SOE, NTT,Indonesia \\ E-mail:faridaniel46@gmail.com
}

\begin{abstract}
Abstrak. Kemampuan berpikirkritismatematika siswa kelas VIII SMP Negeri 3 Soe rendah. Upaya peningkatannya diterapkan model PjBL berpendekatan saintifik. Penelitian bertujuan untuk mengetahui perbedaan kemampuan berpikir kritis pada kedua kelas sampelberdasarkan kategori kemampuan awal yaitu kategori atas, menengahdan bawah.Penelitian ini menggunakan metode kuantitatifmodelquasi eksperimen. Hasil penelitian menunjukkan bahwa kemampuan berpikir kritis siswa pada kelas yang diajarkan model PjBL berpendekatan saintifik lebih baik dari siswa yang diajarkan tanpa model tersebut pada ketiga kategori yaitu kategori atas, menengah dan bawah. Perbedaan yang paling tinggi terdapat pada kategori bawah sehingga model PjBL berpendekatan saintifik paling efektif dalam meningkatkan kemampuan berpikir kritis untuk siswa pada kategori kemampuan awal yang rendah.
\end{abstract}

Kata Kunci: Berpikir Kritis, Model PjBL, Saintifik

\section{PENDAHULUAN}

Pembelajaran matematika di sekolah tidak hanya berkaitan dengan penguasaan materi matematika sebanyak-banyaknya, melainkan juga untuk mencapai tujuan-tujuan yang lebih tinggi misalnya kemampuan berpikir siswa. Dewey dalam [1] mengatakan bahwa sekolah harus mengajarkan cara berpikir yang benar pada anakanak. Selanjutnya menurut Ruggiero berpikir adalah segala aktivitas mental yang membantu merumuskan atau memecahkan masalah, membuat keputusan, atau memenuhi keinginan untuk memahami; berpikir adalah sebuah pencarian jawaban, sebuah pencapaian makna [1].

Menurut Ennis dalam[2] berpikir kritis adalah berpikir secara beralasan dan reflektif yang masuk akal atau berdasarkan nalar dengan menekankan pada pembuatan keputusan tentang apa yang harus dipercayai atau diyakini untuk menentukan apa yang akan dikerjakan. Kemampuan berpikir kritis dapat bermanfat untuk menghadapi berbagai kemungkinan dan memiliki karakteristik yang paling mungkin dapat dikembangkan melalui pembelajaran matematika [3].
Geometri merupakan salah satu cabang matematika yang menempati posisi strategis untuk mengembangkan kemampuan berpikir kritis. Geometri berfungsi untuk mengembangkan kemampuan berpikir analitis, kritis dan kreatif dan juga penting bagi siswa untuk meningkatkan wawasan keruangan. Hasil wawancara dengan salah satu guru mata pelajaran matematika di SMP Negeri 3 Soe, kabupaten Timor Tengah Selatan propinsi Nusa Tenggara Timur, diketahui bahwa banyak siswa kesulitan menyelesaikan soal-soal geometri. Siswa hanya mengerjakan soal dengan berfokus pada penggunaan rumus. Dari pekerjaan siswa pada ulangan harian materi geometri yaitu materi Bangun Ruang Sisi Datar siswa kelas VIII tahun pelajaran 2013/2014 lalu diketahui kesulitan tersebut dikarenakan siswa masih belum terbiasa dan kurang kritis saat berhadapan dengan soal-soal non rutin karena kemampuan matematika siswa masih rendah.

Berdasarkan fakta yang ditemukan, perlu dilakukan usaha untuk meningkatkan kemampuan berpikir kritis melalui pembenahan dalam proses pembelajaran. Dibutuhkan suatu model pembelajaran yang mendukung peningkatan kemampuan berpikir kritis siswa. Model Project 


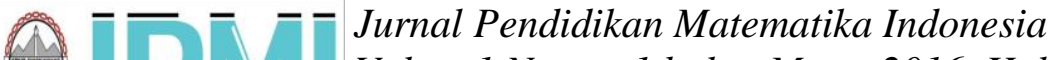

Based Learning (PjBL) dapat diterapkan dalam mengatasi masalah yang timbul selama proses pembelajaran. Alasan rasional penggunaan model ini adalah model ini berbasis proyek dan memberikan kesempatan kepada para siswa untuk menggali konten (materi) dengan menggunakan berbagai cara yang bermakna bagi dirinya dan melakukan eksperimen secara kolaboratif. Model ini menuntut pengajar dan atau siswa mengembangkan pertanyaan penuntun (a guiding question) dalam memecahkan sebuah masalah yang diberikan sehingga melatih siswa berpikir kritis.

Menurut Jones, Rasmussen dan Moffitt sebagaimana dikutip oleh [4], PjBL adalah tugastugas yang diberikan berdasarkan pertanyaan atau masalah-masalah yang menantang, melibatkan siswa dalam perancangan, pemecahan masalah, memberi keputusan, atau menyelidiki aktivitas, memberikan pada siswa hak secara otonomi selama periode waktu dan berujung pada produk nyata atau presentasi. Model PjBL yang disajikan dengan pendekatan scientific (saintifik)atau yang lebih umum dikatakan pendekatan ilmiah, diharapkan akan mendorong siswa lebih aktif dan tidak cepat menyerah saat menghadapi kesulitan dalam pembelajaran. Pendekatan saintifiksendiri dalam pembelajaran meliputi kegiatan mengamati, menanya, menalar, mencoba, dan mengkomunikasikan sehingga akan memperkuat penalaran dan sikap kritis siswa dalam rangka pencarian (penemuan) jawaban dan pengerjaan proyek yang diberikan kepadanya. Oleh karena itu, siswa akan memahami bagaimana pentingnya belajar matematika dan secara tidak langsung siswa akan termotivasi untuk belajar matematika.

Tujuan penelitian ini adalah menghasilkankajian mengenai perbedaan kemampuan berpikir kritis antara siswa pada kelas yang mendapat pembelajaran model PjBL berpendekatan saintifik dengan siswa pada kelas yang tidak mendapatkan pembelajaran dengan model tersebut berdasarkan kategori kemampuan awal siswa.

PjBL merupakan model pembelajaran yang memberikan kebebasan kepada siswa untuk merencanakan aktivitas belajar, melaksanakan proyek secara kolaboratif, dan pada akhirnya menghasilkan produk kerja yang dapat dipresentasikan kepada orang lain [5]. PjBL didasarkan pada teori konstruktivisme, berhubungan dengan psikologi kognitif dan konsep pembelajaran dalam konteks. Tujuan utama dari PjBL adalah untuk menghilangkan fenomena lambannya pengetahuan siswa, dan membuat siswa memiliki kemampuan pemecahan masalah, meningkatkan motivasi belajar siswa, kemampuan berpikir kritis, keterampilan komunikasi, dan kemampuan mengumpulkan data.

PjBL merupakan model yang menggunakan belajar kontekstual, dimana para siswa berperan aktif untuk memecahkan masalah,mengambil keputusan,meneliti,mempresentasikan dan membuat dokumen [6]. PjBL dirancang untuk digunakan pada permasalahan kompleks yang diperlukan siswa dalam melakukan investigasi dan memahaminya. PjBL bisa memastikan hasil yang lebih efektif dengan memungkinkan siswa untuk berpartisipasi aktif dalam proses pembelajaran dan memungkinkan mereka untuk menghasilkan sesuatu dan bekerjasama dengan orang lain [7].

Langkah-langkah pembelajaran dalam $\mathrm{PjBL}$ sebagaimana yang dikembangkan oleh [8] terdiri dari:

\section{a. Start With the Essential Question}

Pembelajaran dimulai dengan pertanyaan esensial, yaitu pertanyaan yang dapat memberi penugasan siswadalammelakukan suatuaktivitas. Mengambil topik yang sesuaidengan realitas dunia nyata dandimulai dengan sebuah investigasi mendalam. Pengajar berusaha agar topik yang diangkat relevan untuk para siswa.

b. Design a Plan for the Project

Perencanaan dilakukan secara kolaboratif antara pengajar dan siswa. Dengan demikian siswa diharapkan akan merasa "memiliki" atas proyek tersebut. Perencanaan berisi tentang aturan main, pemilihanaktivitas yang dapat mendukung dalam menjawab pertanyaan esensial, dengan cara mengintegrasikan berbagai subjek yang mungkin, serta mengetahui alat dan bahan yang dapat diakses untuk membantu penyelesaian proyek.

c. Create a Schedule 
Pengajar dansiswa secara kolaboratif menyusun jadwal aktivitas dalam menyelesaikan proyek. Aktivitas pada tahap ini antara lain: (1) membuatwaktuuntukmenyelesaikanproyek, (2) membuat batas waktu penyelesaian proyek, (3)membawasiswa agar merencanakan cara yang baru, (4) membimbing siswa ketika mereka membuatcarayang tidakberhubungandenganproyek, dan (5) meminta siswa untuk membuatpenjelasan (alasan) tentang pemilihan suatu cara.

d. Monitor the Students and the Progress of the Project

Pengajar bertanggungjawab untuk melakukan monitor terhadap aktivitas siswa selama menyelesaikan proyek. Monitoring dilakukan dengancaramemfasilitasi siswa pada setiap proses. Dengan kata lain pengajar berperanmenjadi mentor bagi aktivitassiswa. Agar mempermudah proses monitoring, dibuat sebuahrubrik yang dapat merekam keseluruhanaktivitas yang penting.

e. Assess the Outcome

Penilaian dilakukan untuk membantu pengajar dalam mengukur ketercapaian standar, berperan dalam mengevaluasi kemajuan masing-masing siswa, memberi umpan balik tentang tingkat pemahaman yang sudah dicapai siswa, membantu pengajar dalam menyusun strategi pembelajaran berikutnya.

f. Evaluate the Experience

Padaakhir proses pembelajaran, pengajar dansiswa melakukan refleksi terhadap aktivitasdan hasil proyek yang sudahdijalankan. Proses refleksi dilakukan baik secaraindividu maupun kelompok. Pada tahap ini siswa diminta untuk mengungkapkan perasaan dan pengalamannya selama menyelesaikan proyek. Pengajar dan siswa mengembangkan diskusi dalam rangka memperbaiki kinerja selama proses pembelajaran, sehingga pada akhirnya ditemukan suatu temuan baru(new inquiry) untuk menjawab permasalahan yang diajukan pada tahap pertama pembelajarannya.

Penerapan pendekatan saintifik/ilmiah dalam pembelajaran menuntut adanya perubahan setting dan bentuk pembelajaran tersendiri yang berbeda dengan pembelajaran tradisional. Model yang dipandang sejalan dengan prinsip pendekatan saintifik/ilmiah adalah problem based learning, $\mathrm{PjBL}$, inkuiri, dan group investigation. Modelmodel tersebut mengajarkan kepada siswa untuk mengenal masalah, merumuskan masalah, mencari solusi, menguji jawaban sementara dengan melakukan penyelidikan (menemukan fakta-fakta melalui penginderaan), dan pada akhirnya menarik simpulan dan menyajikan secara lisan maupun tertulis.

[9] memberikan konsepsi bahwa pendekatan ilmiah (scientific approach) dalam pembelajaran mencakup komponen:

a. Mengamati

Mengamati dapat dilakukan antara lain melalui kegiatan mencari informasi, melihat, mendengar, membaca, dan atau menyimak.

b. Menanya

Menanya untuk membangun pengetahuan siswa secara faktual, konseptual, dan prosedural, hingga berpikir metakognitif, dapat dilakukan melalui kegiatan diskusi, kerja kelompok, dan diskusi kelas.

c. Mencoba

Mengeksplor/mengumpulkan informasi, atau mencoba untuk meningkatkan keingintahuan siswa dalam mengembangkan kreatifitas, dapat dilakukan melalui membaca, mengamati aktivitas, kejadian atau objek tertentu, memperoleh informasi, mengolah data, dan menyajikan hasilnya dalam bentuk tulisan, lisan, atau gambar.

d. Mengasosiasi

Mengasosiasi dapat dilakukan melalui kegiatan menganalisis data, mengelompokan, membuat kategori, menyimpulkan dan memprediksi atau mengestimasi.

e. Mengkomunikasikan

Mengomunikasikan adalah sarana untuk menyampaikan hasil konseptualisasi dalam bentuk lisan, tulisan, gambar/sketsa, diagram, atau grafik, dapat dilakukan melalui presentasi, membuat laporan, dan atau unjuk kerja.

Berpikir kritis membutuhkan usaha seseorang untuk mengumpulkan, menafsirkan, menganalisis dan mengevaluasi informasi untuk tujuan tiba pada suatu kesimpulan yang dapat diandalkan dan valid [10]. Berpikir kritis merupakan perwujudan dari berpikir tingkat tinggi (high order 
thinking).Dengan melibatkan siswa secara aktif dalam kegiatan berbasis proyek atau kolaboratif dapat mendorong pengembangan berpikir kritis jika instruksi model proses berpikir, menggunakan teknik interogasi yang efektif dan membimbing siswa proses berpikir kritis [11]. Efektivitas instruksi berpikir kritis dipengaruhi oleh kondisi lingkungan instruksional yang terdiri dari variabel pembelajaran (strategi pengajaran dan pendekatan instruksional berpikir kritis), dan sampai batas tertentu dari variabel yang berhubungan dengan siswa [12].

Krulik dan Rudnick dalam [13] membagi indikator kemampuan berpikir kritis kedalam beberapa bagian, yaitu (1) pengujian, penghubungan, pengevaluasian semua aspek dari suatu situasi atau masalah; (2) penetapan fokus pada bagian dari situasi atau masalah; (3) pengumpulan dan pengorganisasian informasi; (4) validasi dan menganalisis informasi; (5) penentuan kelayakan suatu jawaban; (6) penarikan kesimpulan yang valid; (7) analisis dan refleksif di alam nyata.

Glazer dalam [13] menyatakan terdapat tiga indikator dalam berpikir kritis, yaitu (1) pembuktian, yakni kemampuan untuk membuktikan suatu pernyataan secara deduktif (menggunakan teori-teori yang telah dipelajari sebelumnya); (2) generalisasi adalah kemampuan untuk menghasilkan pola atas persoalan yang dihadapi untuk kategori yang lebih luas; (3) pemecahan masalah, yakni kemampuan mengidentifikasi unsur yang diketahui, dinyatakan, dan memeriksa kecukupan unsur yang diperlukan dalam soal, menyusun model matematika dan menyelesaikannya serta memeriksa kebenaran hasil atau jawaban.

Berdasarkan pendapat-pendapat di atas, indikator berpikir kritis yang akan digunakan dalam penelitian ini adalah perpaduan indikator berpikir kritis yang dikemukakan Krulik dan Rudnick dalam [13] yaitu analisis dan refleksif di alam nyata dengan indikator berpikir kritis yang dikemukakan oleh Glazer dalam [13] yaitu generalisasi. Hal ini dimaksudkan untuk mengukur kemampuan siswa dalam melakukan pengamatan, penyelidikan, mencoba suatu proses, menemukan, menyimpulkan dan membangun pengetahuannya sendiri. Dari kajian teori tentang kemampuan berpkir kritis diatas, dapat digunakan untuk membuat kisi-kisi tes kemampuan berpikir kritis dan selanjutnya membuat tes kemampuan berpikir kritis.

\section{METODE}

Penelitian ini adalah penelitian kuantitatif mengikuti model quasi-experimental yang didesaindalam bentuk non-equivalent (pre-test and post-test) control-group design[14]. Desain penelitian ini melibatkan dua kelas sampel, yaitu kelas eksperimendan kelas kontrol. Kedua kelas diberi pre-test untuk mengetahui kemampuan awal siswa. Kelas eksperimen dikenai perlakuan/treatmentyakni pembelajaran dilaksanakan dengan menggunakan model $\mathrm{PjBL}$ berpendekatan saintifik sedangkan kelas kontrol dilaksanakan pembelajaran seperti biasa tanpa menggunakan model pembelajaran tersebut. Pada akhir pembelajaran, dilaksanakan post-test bagi siswa pada kedua kelas untuk mengetahui kemampuan berpikir kritis siswa.

Populasi pada penelitian ini adalah seluruh siswa kelas VIII SMP Negeri 3 Soe. Sampel pada penelitian ini dipilih dengan menggunakan teknik cluster random sampling. Teknik ini digunakan untuk menentukan sampel bila obyek yang akan diteliti (sumber) data sangat luas [15]. Pada penelitian ini teknik tersebut digunakan untuk menentukan satu kelas eksperimen dan satu kelas kontrol. Pembelajaran pada kelas eksperimen menggunakan model $\mathrm{PjBL}$ berpendekatan saintifik sedangkan pembelajaran pada kelas kontrol menggunakan pembelajaran langsung.

Teknik pengumpulan data berupa Tes Kemampuan Berpikir Kritis (TKBK). Soal TKBK yang diberikan berbentuk essay test. Analisis data menggunakan uji normalitas dan uji homogenitas sebagai uji prasyarat, dilanjutkan dengan uji kesamaan rata-ratadanujianova 2 jalur. Uji kesamaan dua rata-rata bertujuan untuk mengetahui rata-rata kemampuan awal kedua kelas sebelum pembelajaran sama. Uji anova 2 jalur digunakan untuk mengetahui perbedaan ratarata nilai TKBK padakelas eksperimen dan kelaskontrolberdasarkankategorikemampuanawals iswa. 


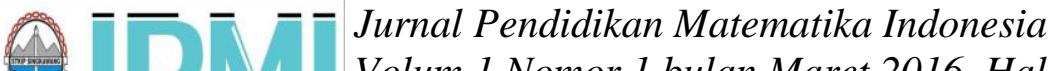 \\ Volum 1 Nomor 1 bulan Maret 2016. Halaman 7-13 \\ p-ISSN: 2477-5967 e-ISSN: 2477-8443}

\section{HASIL DAN PEMBAHASAN}

Hasil penelitian yang diperoleh menunjukkan bahwa ada perbedaan kemampuan berpikir kritis antara siswa pada kelas yang mendapat pembelajaran model PjBL berpendekatan saintifik dengan siswa pada kelas yang tidak mendapatkan pembelajaran dengan model tersebut. Begitu juga untuk kemampuan berpikir kritis siswa disetiap kategori baik kategori atas, menengah dan bawah dari kedua kelas semuanya berbeda. Karena terdapat perbedaan maka dilakukan uji lanjutanuntuk mengetahui perbedaan yang terjadi tersebut.

Hasil uji lanjutan kemudian menunjukkan bahwa kemampuan berpikir kritis siswa yang mendapat pembelajaran model PjBL berpendekatan saintifik lebih baik dari kemampuan berpikir kritis siswa pada kelas yang tidak mendapatkan pembelajaran dengan model tersebut pada ketiga kategori yaitu kategori atas, menengah dan bawah. Perbedaan antara tiap kategori pada kedua kelas dapat juga dilihat pada Gambar 1 dan Gambar 2.

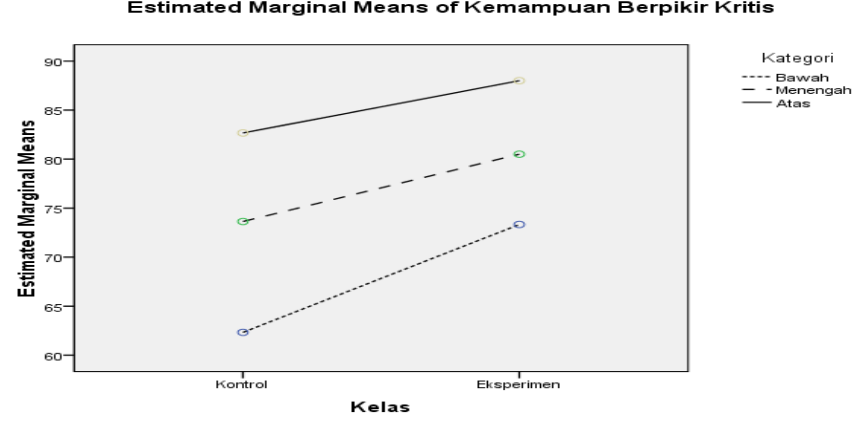

Gambar. 1Kemampuan Berpikir Kritis Siswa Berdasarkan Kelas

Berdasarkan Gambar 1 menunjukkan bahwa kemampuan berpikir kritis siswa kelas eksperimen lebih baik dari kemampuan berpikir kritis siswa kelas kontrol pada setiap kategori baik kategori atas, menengah dan bawah. Perbedaan yang paling tinggi terdapat pada kategori bawah sehingga model PjBL berpendekatan saintifik paling efektif dalam meningkatkan kemampuan berpikir kritis untuk siswa pada kategori kemampuan awal yang rendah.
Estimated Marginal Means of Kemampuan Berpikir Kritis

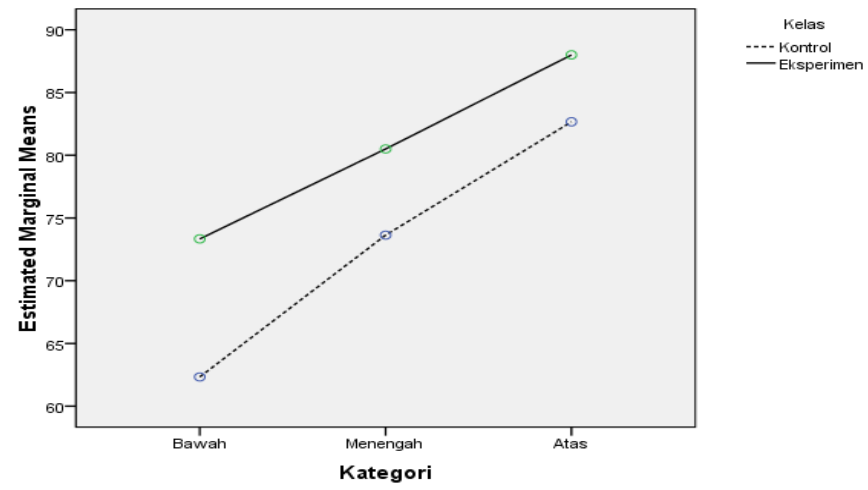

Gambar 2. Kemampuan Berpikir Kritis Siswa Berdasarkan Kategori

Berdasarkan Gambar 2 menunjukan kemampuan berpikir kritis siswa pada kategori atas pada kelas kontrol lebih baik dari kemampuan berpikir kritis siswa kategori menengah dan bawah kelas eksperimen dan juga lebih baik dari kemampuan berpikir kritis siswa menengah dan bawah pada kelas kontrol. Demikian juga untuk kemampuan berpikir kritis siswa kategori menengah pada kelas kontrol lebih baik dari kemampuan berpikir kritis siswa kategori bawah kelas eksperimen dan juga lebih baik dari kemampuan berpikir kritis siswa kelas bawah kelas kontrol.

Adanya perbedaan kemampuan berpikir kritis siswa pada kedua kelas disebabkan karena perlakuan pembelajaran yang berbeda pada kedua kelas tersebut. Pada kelas yang diajarkan menggunakan model PjBL berpendekatan saintifik pembelajarannya terpusat pada siswa dan peran guru adalah sebagai fasilitator dan motivator. Siswa bekerja secara berkelompok sesuai tahapan PjBL untuk membangun pengetahuannya sendiri dan bekerjasama dengan teman dalam penyelesaian proyek dan latihan soal. Hal ini sesuai dengan teori konstruktivisme dalam pembelajaran matematika yaitu bahwa peranan guru bukan sebagai pemberi jawaban akhir atas pertanyaan siswa melainkan mengarahkan mereka untuk membentuk (mengkonstruksi) pengetahuan matematika sehingga diperoleh struktur matematika seperti yang dikemukakanoleh[16]. Pada kelas yang tidak diajarkan dengan model PjBL berpendekatan saintifik siswa menerima penjelasan langsung dari guru seperti biasa. 
Penjelasan tersebut berupa definisi, rumus, contoh soal dan soal latihan untuk dikerjakan oleh siswa.

Perbandingan kemampuan berpikir kritis kedua kelas penelitian pada uji lanjutan adalah kemampuan berpikir kritis siswa kelas eksperimen lebih baik dari kelas kontrol. Ini disebabkan peran siswa dalam mengkonstruksi ide, menganalisis dan merefleksikan masalah kemudian berusaha memecahkannya, serta melakukan generalisasi lebih baik ketika mendapat pembelajaran model PjBL berpendekatan saintifik. Hal ini sesuai dengan hasil penelittian [11] yang menyimpulkan bahwa untuk menanamkan keterampilan berpikir kritis siswa dalam kelas maka siswa tidak menjadi penerima informasi, tetapi sebagai penggunainformasi. Lingkungan belajar yang secara aktif melibatkan siswadalam penyelidikan informasi dan penerapan pengetahuanakan mempromosikan keterampilan berpikir kritissiswa. Hasil penelitian dari [17] juga mengemukakan bahwa pembelajaran dengan model PjBL lebih efektif daripada pembelajaran model tradisional dilihat pada prestasi belajar matematika siswa. PjBL mempunyai pengaruh yang positif terhadap sikap belajar siswa karena dengan menyelesaikan proyek dalam kelompok siswa menjadi lebih kreatif dan mampu bekerja sama.

Pembelajaran model PjBL berpendekatan saintifik mendorong siswa lebih aktif dan lebih memahami konsep ketika melakukan proyek dibandingkan langsung menerima defenisi dan rumus sehingga ketika berhadapan dengan soalsoal geometri non rutin yang sifatnya menantang mereka jauh lebih siap dan kritis dalam menyelesaikannya. Hal ini sejalan dengan hasil penelitian [7] yang menyimpulkan bahwa siswa yang diajar menggunakan model PjBL lebih baik dalam hal keterampilan belajar mandiri daripada siswa yang diajar menggunakan model konvensional. Begitu juga dengan penelitian dari dari [5] bahwa pembelajaran model PjBL meningkatkan hasil belajar siswa.

Hasil post-test kemampuan berpikir kritis siswa pada kelas dengan pembelajaran model PjBL berpendekatan saintifik menunjukkan peningkatan dari hasil pre-test dan pada uji lanjutan juga lebih baik dari kemampuan berpikir kritis siswa pada kelas tanpa model pembelajaran tersebut untuk semua kategori baik kategori atas, menengah dan bawah. Ini berarti selain model pembelajaran, kemampuan awal siswa juga mempengaruhi belajar siswa. Proses asimilasi pengetahuan yang telah dimiliki siswa sebelum pembelajaran dengan pengetahuan baru yang diperoleh dalam pembelajaran akan berjalan baik jika siswa memiliki pengetahuan awal yang cukup. Hasil ini sesuai dengan teori belajar dari Ausubel tentang belajar bermakna. Belajar bermakna merupakan suatu proses dikaitkannya informasi baru pada konsep-konsep relevan yang terdapat dalam struktur kognitif seseorang [18].

\section{KESIMPULAN DAN SARAN}

KESIMPULAN

Berdasarkan hasil dan pembahasan maka diperoleh kesimpulan pada penelitian iniyaituterdapat perbedaan antara kemampuan berpikir kritis pada kelas yang diajarkan dengan model PjBL berpendekatan saintifik dengan kelas yang tidak menggunakan model tersebut berdasarkan kategori kemampuan awal siswa. Kemampuan berpikir kritis siswa pada kelas yang diajarkan dengan model PjBL berpendekatan saintifik lebih baik dari kelas yang diajarkan tanpa menggunakan model pembelajaran tersebut baik pada kategori atas, bawah dan menengah.

SARAN

Berdasarkan kesimpulan di atas, maka dapat disarankan beberapa hal, sebagai berikut.

a. Bagi guru, model PjBL berpendekatan saintifik dapat digunakan pada topik pembelajaran yang lain dalam pembentukan kemampuan berpikir kritis siswa. Dalam implementasinya model ini akan lebih baik jika guru lebih kreatif merancang kerangka proyek yang tepat, sesuai dengan tujuan pembelajaran yang akan dicapai serta didukung oleh fasilitas yang memadai dan juga alokasi waktu yang tepat. Guru juga hendaknya memotivasi siswa untuk mempunyai karakter kerja keras dalam kehidupannya serta membimbing siswa agar terampil dalam mempersiapkan proses pembelajaran. 


\section{O.JPMI}

b. Bagi siswa, sangat dibutuhkan adanya kemampuanberpikirkritis dalam belajar khususnya dalam proses pembelajaran karena sangat mempengaruhi hasil belajarnya.

c. Bagi peneliti selanjutnya, dapat dijadikan sebagai referensi mencoba menggunakan model PjBL pada materi yang lain.

\section{DAFTAR PUSTAKA}

[1] Johnson, E. B. CTL Contextual teaching and Learning; Menjadikan Kegiatan Belajar-Mengajar Mengasyikan dan Bermakna. Terjemahan Ibnu Setiawan. Bandung : Kaifa. 2014

[2] Fatmawati, H. Mardiyana dan Trianto. “Analisis Berpikir Kritis Siswa dalam Pemecahan Masalah Matematika Berdasarkan Polya Pada Pokok Bahasan Persamaan Kuadrat (Penelitian Pada Siswa Kelas X Smk Muhammadiyah 1 Sragen Tahun Pelajaran 2013/2014)".Jurnal Elektronik Pembelajaran Matematika.Vol.2. No.9. Hal 899-910. 2014.

[3] Depdiknas. Kurikulum Standar Kompetensi Matematika Sekolah Menengah Pertama dan Madrasah Tsanawiyah. Jakarta: Depdiknas. 2006.

[4] Thomas, J.W. A Review of research On Project Based Learning. Tersedia http://.ble.org/research/study/reviewofprojectbasedlearning.(diakses 7 Desember 2014). 2000.

[5] Wang, B. T., Teng, C. W. \& Lin Y. H. "Let's Go Traveling - ProjectBased Learning in a Taiwanese Classroom". International Journal of Information and Education Technology. Vol. 5, No. 2. Hal 84-88. 2015

[6] Guo, S., \& Yang, Y. "Project-Based Learning: an Effective Approach to Link Teacher Professional Development and Students Learning". Journal of Educational Technology Development and Exchange. Vol.5. No. 2. Hal. 41-56. 2012

[7] Bagheri M. dkk. "Effects of Project-based Learning Strategy on Selfdirected Learning Skills of Educational Technology Students". Contemporary Educational Technology. Vol. 4. No. 1. Hal. 15-29. 2013.
[8] The George Lucas Educational Foundation. Instructional Project Based Learning. Tersedia di http://www.edutopia.org. (diakses 12 November 2014). 2005

[9] Kementerian Pendidikan dan Kebudayan. Pendekatan Scientific (Ilmiah) dalam Pembelajaran. Jakarta: Pusbangprodik. 2013.

[10]Chukwuyenum, A. N. "Impact of Critical thinking on Performance in Mathematics among Senior Secondary School Students in Lagos State". IOSR Journal of Research \& Method in Education. Vol. 3. No. 5. Hal. 18-25. 2013.

[11]Peter, E. E. "Critical thinking: Essence for teaching mathematics and mathematics problem solving skills".African Journal of Mathematics and Computer Science Research. Vol. 5. No. 3. Hal. 39-43. 2012.

[12] Tiruneh, D. T., Verburgh, An., \& Elen, J. "Effectiveness of Critica Thinking Instruction in Higher Education: A Systematic Review of Intervention Studies". Higher Education Studies. Vol. 4, No. 1. Hal. 1 17. 2014.

[13]Firdaus, dkk."Developing Critical Thinking Skill of Students in Mathematics Learning”.Journal of Education and Learning. Vol 9.No 3. Hal 226-236. 2015.

[14] Creswell, J. W. Research Design Pendekatan Kualitatif, Kuantitatif dan Mixed. Terjemahan Achmad Fawaid. Yogyakarta: Pustaka Pelajar. 2014.

[15] Sugiyono. Metode Penelitian Kuantitatif, Kualitatif dan R\&D. Bandung: Alfabeta. 2012

[16] Suherman, E. dkk. Strategi Pembelajaran Matematika Kontemporer Bandung: UPI. 2006.

[17] Ozdemir, A. S., Yildiz, F.,Yildiz, S. G. "The Effect of Project Based Learning in "Ratio, Proportion and Percentage" Unit on Mathematics Success and Attitude” . European Journal of Science and Mathematics Education. Vol. 3, No. 1, Hal 1 - 13. 2015.

[18] Trianto. Model-Model Pembelajaran Inovatif Berorientasi Konstruktivisme. Surabaya: Prestasi Pustaka. 2007. 